\title{
Community Involvement in the Beach Tourism Industry in the Province of Batangas, Philippines
}

\author{
Dr. Sherry Joy Abanilla-Del Mundo, LPT \\ College of Arts and Sciences, Batangas State University, Philippines \\ Email id: emmanuelalbertdelmundo@gmail.com
}

\begin{abstract}
This study looked into the extent of community involvement in the beach tourism industry in the Province of Batangas, Philippines in the specific areas of peace and security, marketing and promotion and environmental protection.
\end{abstract}

The descriptive method of research was utilized using a self-constructed questionnaire in order to gather the data needed for the study. The research settled on restricting the paper sample size to 400 respondents as based from a matrix which showed the actual number of the participants, resort owners, resort managers, domestic tourists and foreign visitors as well as the residents of the municipalities under focus. Except for the Provincial Tourism officials and staff, all other respondents were identified from the four selected municipalities of the Province of Batangas.

The results of the study revealed that Batangas, Philippines is a beach tourism haven which gives high regard to a quiet and peaceful community, is beaming with pride of the existence of such beach tourist destinations in their respective localities and advocates the protection and preservation of the environment.

Keywords - beach tourism, peace and security, marketing and promotion, environmental protection, resort owners and managers, Province of Batangas, Philippines.

\section{INTRODUCTION}

According to the Tourism Society and the United Nations World Tourism Organization Statistics Guidelines of 2010, tourism is the generic term used to cover both demand and supply that has been adopted in various forms and is used throughout the world.

Touris $m$ is one of the world's fastest growing industries as well as the major source of foreign exchange earnings and employment for many developing countries. It is a leisure activity which involved a discretional use of time and money. Recreation is often the main purpose for participation in tourism (Ghosh, 2001) either domestic or international. In domestic tourism, people move within their own country whereas in international tourism, the barriers exist in travelling destinations beyond national boundaries where both has incoming and outgoing implications on a country's balance of payments. Today, tourism is not only a concept of enjoyment or travelling or passing the holidays, but also a means of development for developed, developing and underdeveloped countries Tourism brings in large amounts of income into a local economy in the form of payment for goods and services needed by tourists, accounting for $30 \%$ of the world's trade of services, and $6 \%$ of overall exports of goods and services. It also creates opportunities for employment in the service sector of the economy as sociated with touris m The service industries which benefited from tourism include transportation services, such as airlines, cruise ships, and taxicabs; hospitality services, such as accommodations, including hotels and resorts; and entertainment venues, such as amusement parks, casinos, shopping malls, music venues, and theatres. Undoubtedly, tourism holds the promise of increased employment and income opportunities, particularly for Filipinos living in the coastal and rural areas of the country. Yet, it is an industry built upon the most fragile of natural and cultural environments, where the most inconsequential and innocent of human gestures can easily wreak havoc on the site's resources. This is the challenge of sustainable tourism development. Tourism is expected to become an even more important weapon in the Philippines' economic arsenal. However, both our tourist markets and the Philippine tourism industry itself have become more aware of the negative environmental and social costs associated with tourism development. The country has thus begun to recognize the need to adopt new development approaches in order to come up with tourist products that are environmentally sensitive and economically viable. (WTO, 2005)

CALABARZON is one of the regions of the Philippines and also part of the Metro Luzon Urban Beltway or simply Luzon Urban Beltway. It is also designated as Region IV-A and its regional capital is Calamba City in 
Laguna. The region is composed of five provinces, namely: Cavite, Laguna, Batangas, Rizal, and Quezon. The region's name is a portmanteau of the names of these provinces. The region is located in southwestern Luzon, just south and west of Metro Manila and is the second most densely populated region. CALABARZON can be positioned as a tourism destination through the development of its potential tourism assets; particularly those based on the environment, history and culture, the rehabilitation and restoration of existing tourism attractions, improvement of access infrastructure, and the provision of basic facilities and services required to ease travel movements. The provinces are endowed with diverse and rich natural resources, warm and hospitable people, with unique attractions that could initially be of national significance. (Lancion, 1999)

The beach tourism industry, also popularly known as coastal tourism industry, in Batangas is considered a budding investment on this part of the region. Batangas as part of the CALABARZON Region is rich in Filipino traditions and tourist destinations. Making the province famous in beaches, food and native products would create jobs and opportunities to promote the culture and sustain the good character of the Filipinos. Tourism has effect on the social, economic, environmental, cultural heritage and arts (Aguda, Tamayo \& Barlan, 2013) of certain tourist destinations. It is a fast growing industry that has become a top priority of the economic agenda of a number of countries. It is believed that touris m can be used as a tool to solve problems like unemployment and poverty in developing countries. Batangas is a province of the Philippines located on the southwestern part of Luzon in the CALABARZON region. Its capital is Batangas City and it is bordered by the provinces of Cavite and Laguna to the north and Quezon to the east. Across the Verde Is lands Passages to the south is the Island of Mindoro and to the west lies the South China Sea. Batangas is one of the most popular tourist destinations near Metro Manila. The province has many beaches and famous for excellent diving spots only a few hours away from Manila. Found in the province is world-known dive sites that are ideal for observing marine life, and outstanding for macro photography. Located only 110 kilometers south of Metropolitan Manila, it is very accessible by land or by sea. It reigns as the most culturally preserved sites of the Spanish colonial era in the Philippines. Batangas is also generally accepted by linguists as the 'Heart of the Tagalog Language. Poetically, Batangas is often referred to by its ancient name Kumintang. Batangas is located on the southwestern part of Luzon in the CALABARZON Region. Batangas City being its capital is blessed with its accessibility to neighboring provinces such as Laguna, Cavite and Quezon and its proximity to Metro Manila. This makes the place more accessible to both domestic and international tourists. Relative to the issues that the province is beautifully surrounded by seas, mountains and rivers, the protection and management of its endowed beauty and gift of nature have been recommended to be preserved and sustained. The many beaches famous for excellent diving spots that is ideal for observing marine life, fiestas, festivals, the world's lowest volcano, and other outstanding attraction potential for ecotourism sites and activities. (Mejia, Festijo, Borbon and Barlan, 2013). The coastal or beach tourism and recreation are important parts of the largest and most rapidly growing activity in the world (Houston, 1995). This topic embraces the full range of tourism, leisure and recreational oriented activities that take place in the coastal zone and the off shore coastal waters across the world/globe. They include coastal tourism development, for instance, the hotels, resorts, restaurants, food industry, vacation homes, second homes and so on, the infrastructural facilities supporting coastal development like retail businesses, marinas, dive shops, fishing tackle stores, recreational boating harbors, beaches, fishing facilities, boating, cruises, swimming, snorkeling and diving as well as public and private programs affecting the aforementioned activities (Houston, 1995).

However, the relationship between coastal areas and tourism is as old as tourism itself. Early tourists favored seaside locations and made journeys to fashionable resorts to bathe in sea water to take advantage of its alleged curative powers. This was a major departure in the eighteenth century from a time when the sea and coast were revered as places and even feared (Lenček and Bosker, 1999). For them, "the beach historically speaking is a recent phenomenon. In fact, it took hundreds of years for the seashore to be colonized as the preeminent site for human recreation and the coast continues to be one of the most important environments for tourism in contemporary times building on its established heritage". Hall and Page, (2005) observed that; "The coastal environment is a magnet for tourists although its role in leisure activities has changed in time and space, as coastal destinations have developed, waned, been reimaged and redeveloped in the twentieth century. Beach tourism is becoming a highly competitive business as nations actively seek to draw increased numbers of visitors and increased foreign earnings to the shores. However, given today's rapid pace of communication, the existence of poor water quality or degraded or eroding beaches is quickly communicated among networks of travel agents and others in the tourism marketing business. Despite increased awareness of the economic and environmental significance, it is only in recent years that a substantial body of research has emerged. Furthermore, beach touris $m$ is considered to be one of the fastest growing areas of present day tourism which is epitomized by the '3Ss'-sun, sand and sea. In 
order to create safe, stable and attractive coastal environment with clean waters and healthy coastal habitats, it is necessary to develop well managed and sustainable beach tourism. Wong (1993) argued that "it has been established that tourism is environmentally dependent and the unique character of coastal environment gives to various types of tourism development. While there is increasing recognition of the coastal environment as a tourism resource, there is also the need to consider the sustainability of the environment as it continues to open up to the full gamut of tourism activities". He pointed out that although there are many studies on coastal tourism, they tend to emphasize the tourism system rather than the interaction of tourism and environmental systems. Tourism and recreation-related development is one of the major factors shaping development patterns in coastal zones of the nation and the world. Indeed, virtually all coastal and ocean issue areas affect coastal tourism and recreation directly or indirectly. Clean water, healthy coastal habitats, and a safe, secure and enjoyable environment are clearly fundamental to successful coastal tourism. Similarly, bountiful living marine resources (fish, shellfish, wetlands, coral reefs and so on) are of critical importance to most recreational experiences. Security from risks associated with natural coastal hazards such as storms surge, hurricanes, tsunamis and the like is a requisite for coastal tourism to be sustainable over the long term (Wong, 1993). This study focused on the Province of Batangas as its locale. The province is part of the CALABARZON portmanteau which is also known as Region IV-A. Separating from MIMAROPA in 2002, CALABARZON can be positioned as a tourism destination by virtue of Executive Order No. 103 through the development of its potential tourism assets particularly those based on the environment, history and culture. (www.wikipedia.com)

As Batangas is a 34-municipality province, Mabini, Lian, Nasugbu, and San Juan are the foremost beach destinations of most tourists in this part of the region. A matrix from the Provincial Tourism and Cultural Affairs Office (PTCAO) of Batangas reflects the top ten resorts and the municipalities located in the province according to tourist arrival from 2012 to 2016. In this light, this paper specifically explored on the involvement of the community in the beach tourism industry in the Province of Batangas.

\section{OBJECTIVES OF THE STUDY}

1. Determine the profile of the beach tourism industry in the Province of Batangas in terms of years of existence, classification, population, geographical dispersion, and sources of livelihood.

2. Verify the extent of involvement of the community in the said tourism industry along items as peace and security, marketing and promotion, and environmental protection.

\section{METHODOLOGY}

The study used the descriptive method of research in order to determine the profile and extent of community involvement in the beach tourism industry in the Province of Batangas. According to Calderon (2008), as cited by Alberto et al (2011), the descriptive method which is also known as statistical research, describes data and characteristics about the population or phenomenon being studied. Often the best approach prior to writing a descriptive research such as this is by conducting a survey investigation which was a method undergone by the researcher.

The researcher settled on restricting the paper sample size to 400 respondents as based from information given by PTCAO to the researcher which showed the actual number of the participants randomly selected from the municipalities of Mabini, Nasugbu, Lian and San Juan. The number of respondents identified was divided by way of the following representations: Provincial Tourism officials and staff, resort owners, resort managers, domestic tourists and foreign visitors and residents of the municipalities under focus. Except for the Provincial Tourism officials and staff, all other respondents were identified from the four selected municipalities of the Province of Batangas. The number of participants to answer the questionnaire was based from the formula presented below:

\section{$400(n)$ / total number of sample per municipality $X$ total sample size per municipality $=$ actual number of participants}

A self - constructed survey questionnaire was used as the main data gathering instrument for the study. The questionnaire was composed of two main sections. The first section contained the profile of the respondents. The second part was the survey proper that explored on the extent of the involvement of the community to the beach tourism industry in the tourist destinations in Batangas. Secondary data were collected and interpreted as they were provided by the Provincial and Municipal Tourism Offices of the areas under focus. Simple statistical tools were used such as percentage, average, and frequency. To fulfill the objectives of the study, data were analyzed descriptively. The interpretation of the total responses of all respondents as to the extent of involvement of the community in the beach tourism industry in their locales used the following scale: $1.00-$ 1.49 as Very Low, 1.50 - 2.49 as Low, 2.50 - 3.49 as 
Moderate, $3.50-4.49$ as High and $4.50-5.00$ as Very High.

\section{RESULTS AND DISCUSSION}

The beach tourism profile considered in this study are years of existence, class, population, geographical dispersion and sources of livelihood.

\section{Years of Existence}

The table below shows the profile of the beach tourism industry in Batangas in terms of years of existence.

Table.1: Profile of the Beach Tourism Industry in Batangas in Terms of Years of Existence

\begin{tabular}{c|c}
\hline Municipality & Years of Existence \\
\hline Mabini & 101 \\
\hline Nasugbu & 167 \\
\hline Lian & 104 \\
\hline San Juan & 171
\end{tabular}

Source: MPDC Reports 2016, Municipalities of Mabini, Nasugbu, Lian and San Juan

The presented data shows that San Juan is the oldest of the four municipalities under scrutiny as it has existed for one hundred seventy one (171) years, followed by Nasugbu which has existed for one hundred sixty seven (167), third is Lian at one hundred four years (104) and the Municipality of Mabini which age as a town is one hundred one years (101).

Class

The table below illustrates the profile of the sun and beach tourism industry in Batangas in terms of classification

Table.2: Profile of the Beach Tourism Industry in Batangas in Terms of Classification

\begin{tabular}{c|l}
\hline Municipality & Class \\
\hline Mabini & First class \\
\hline Nasugbu & First class \\
\hline Lian & Third class \\
\hline San Juan & First class \\
\hline
\end{tabular}

Source: MPDC Reports 2016, Municipalities of Mabini, Nasugbu, Lian and San Juan

With the presented data, these explain that all three (3) municipalities in focus namely Mabini, Nasugbu and San Juan are first class municipalities while Lian is third class in classification.

\section{Population}

The table below presents the profile of the beach tourism industry in Batangas in terms of population.

Table.3: Profile of the Beach Tourism Industry in Batangas in Terms of Population

\begin{tabular}{c|c|c|c}
\hline \multirow{4}{*}{ Municipality } & $\begin{array}{c}\text { Population } \\
\text { NSO } \\
\text { Census } \\
\mathbf{2 0 1 0 -} \\
\mathbf{2 0 1 5}\end{array}$ & $\begin{array}{c}\text { Projected } \\
\text { Population } \\
\text { NSO } \\
\text { Census } \\
\mathbf{2 0 1 6}\end{array}$ & $\begin{array}{c}\text { Projected } \\
\text { Growth } \\
\text { Rate }\end{array}$ \\
\hline Mabini & 44,391 & 48,720 & $1.38 \%$ \\
\hline Nasugbu & 122,483 & 140,402 & $2.21 \%$ \\
\hline Lian & 45,943 & 50,155 & $1.97 \%$ \\
\hline San Juan & 94,291 & 104,589 & $2.18 \%$ \\
\hline Source: Phili
\end{tabular}

Source: Philippine Statistics Authority, 2015

As the presented data reflect, the Municipality of Nasugbu is the most populous in the NSO Census of 2010, NSO Census of 2015 and in the projected population NSO Census of 2016. It also has the highest projected growth rate of $2.21 \%$. The Municipality of San Juan followed next. The least populous municipality appears to be Mabini with a projected growth rate of $1.38 \%$ per year as compared with the second least populous Lian with a projected growth rate of $1.97 \%$ per year.

\section{Geographical Dispersion}

The accessibility of Batangas to all points of origin in the Southern Tagalog area made it a potential tourism hub for beach lovers and nature adventurers seeking for thrilling engagements and activities. Mabini can be accessed through the STAR Tollway and the SLEX pass through, Nasugbu can be reached through either the Batangas tollways or the pass through having Cavie as a starting point. Lian on the other hand is just a good two or three kilometers away from Nasugbu while San Juan which is on the Eastern part of the province of Batangas can be accessed through Lipa City or Batangas City. Truly, the municipalities under focus are accessible to beach enthusiasts who may want to experience the beauty of the province.

Sources of Livelihood

The presented table below illustrates the sources of livelihood the residents of the areas under focus are engaged into. 
Table.4: Profile of the Beach Tourism Industry in Batangas in Terms of Sources of Livelihood

\begin{tabular}{|c|c|c|}
\hline Municipality & $\begin{array}{l}\text { Agriculture } \\
\text { and Fishing } \\
\text { Related }\end{array}$ & $\begin{array}{l}\text { Formal } \\
\text { Employment }\end{array}$ \\
\hline Mabini & $\begin{array}{l}\text { Hog/swine } \\
\text { raising, poultry } \\
\text { raising, } \\
\text { backyard } \\
\text { vegetable } \\
\text { raising and } \\
\text { selling, , deep } \\
\text { sea fishing and } \\
\text { selling }\end{array}$ & \multirow[t]{4}{*}{$\begin{array}{l}\text { work in } \\
\text { factories, } \\
\text { manufacturing } \\
\text { firms, resorts, } \\
\text { health } \\
\text { facilities, } \\
\text { educational } \\
\text { institutions } \\
\text { OFWs }\end{array}$} \\
\hline Nasugbu & $\begin{array}{l}\text { Hog/swine } \\
\text { raising, poultry } \\
\text { raising, sugar } \\
\text { cane growing } \\
\text { and sugar } \\
\text { making } \\
\text { g, salt and } \\
\text { sardine making }\end{array}$ & \\
\hline Lian & $\begin{array}{l}\text { Hog/swine } \\
\text { raising, poultry } \\
\text { raising, sugar } \\
\text { cane growing } \\
\text { and sugar } \\
\text { making } \\
\text { backyard } \\
\text { vegetable } \\
\text { raising and } \\
\text { selling, salt and } \\
\text { bagoong } \\
\text { making }\end{array}$ & \\
\hline San Juan & $\begin{array}{l}\text { Hog/s wine } \\
\text { raising } \\
\text { backyard } \\
\text { vegetable } \\
\text { raising and } \\
\text { selling, pottery } \\
\text { making } \\
\text { banig making, } \\
\text { vinegar } \\
\text { making, } \\
\text { bagoong and } \\
\text { salt making }\end{array}$ & \\
\hline
\end{tabular}

Source: PPDC Reports 2016, Provincial Planning and Development Office

As can be gleaned from the table, the residents of the municipalities under focus are engaged into formal employment, agriculture related and fishing related sources of livelihood. There are commonalities as to the sources of living as discussed which feature the native products being produced by each municipality and the services and expertise which may be provided to the visitors of the beach tourism destinations in their respective areas.

\section{EXTENT OF INVOLVEMENT OF THE COMMUNITY IN BEACH TOURISM INDUSTRY IN BATANGAS}

Peace and Security

Table 5 shows the extent of involvement of the community in the beach tourism industry in Batangas in terms of peace and security.

Table.5: Extent of Involvement of the Community in the Beach Tourism Industry in terms of peace and security

\begin{tabular}{|c|c|c|c|c|c|c|}
\hline \multirow{2}{*}{$\begin{array}{c}\text { The } \\
\text { community.... }\end{array}$} & {$[1]$} & [2] & [3] & [4] & [5] & \multirow{2}{*}{$\begin{array}{r}\mathbf{A W} \\
\mathbf{M}\end{array}$} \\
\hline & VL & $\mathbf{L}$ & $\mathbf{M}$ & $\mathbf{H}$ & VH & \\
\hline $\begin{array}{l}\text { 1.is involved in } \\
\text { ensuring the } \\
\text { safety of visitors } \\
\text { in the place }\end{array}$ & 1 & 4 & 40 & 183 & 172 & 4.30 \\
\hline $\begin{array}{l}\text { 2. helps in } \\
\text { ensuring peace } \\
\text { and security in } \\
\text { the place by } \\
\text { means of } \\
\text { organizing a task } \\
\text { force for the } \\
\text { purpose }\end{array}$ & 1 & 6 & 44 & 182 & 167 & 4.27 \\
\hline $\begin{array}{l}\text { 3. involves itself } \\
\text { on trainings } \\
\text { concerning their } \\
\text { role as guardians } \\
\text { and protectors of } \\
\text { visitors in the } \\
\text { place. }\end{array}$ & 1 & 9 & 60 & 181 & 149 & 4.17 \\
\hline $\begin{array}{c}\text { 4. forms } \\
\text { emergency } \\
\text { services to be } \\
\text { able to serve and } \\
\text { assist travelers } \\
\text { and tourists. }\end{array}$ & 1 & 13 & 46 & 171 & 169 & 4.24 \\
\hline $\begin{array}{c}\text { 5. formulates } \\
\text { ordinances/ laws } \\
\text { on tourism } \\
\text { security and } \\
\text { other measures. }\end{array}$ & 7 & 14 & 47 & 162 & 170 & 4.19 \\
\hline Mean & & & $3(\mathrm{H}$ & h In & emen & \\
\hline
\end{tabular}


With four hundred (400) participants from the areas under study in the Province of Batangas, the indicators used in order to reveal the extent of involvement to the peace and security aspect of the beach tourism industry of the community in Batangas were able to show the following results: The community is highly involved in ensuring the safety of local and foreign visitors in the place where the beach tourist destinations are located with one hundred eighty three (183) participants. The community also showed high to very high involvement in ensuring peace and security in specific beach destinations by means of organizing a task force for the purpose of upholding the safety of tourists coming to the place.

The community also showed willingness to involve itself on trainings concerning their roles as guardians responsible for protecting visitors in the place. One hundred seventy one (171) respondents believed that the community near the sun and beach tourist destinations are very willing to form emergency services (ex. provision of ambulance, fire truck, barangay patrol/service) and groups (ex. barangay police, barangay officials, barangay tanod) to be able to serve and assist travelers and tourists; and, also showed very high involvement in formulating ordinances and laws about tourism security and protection measures.

With a mean of 4.23 , the data strongly disclosed that the residents of the Province of Batangas were highly involved with the concerns on peace and security of the beach destinations in the areas under study. Further, the following data also revealed the high regard of the Batanguenos to protect their visitors and make them feel safe during their stay in particular places offering excellent beach experiences in the province.

\section{Marketing and Promotion}

Table 6 shows the extent of involvement of the community in the sun and beach tourism industry in Batangas in terms of marketing and promotion.

\section{Table.6: Extent of Involvement of the Community in the} Beach Tourism Industry in Batangas in Terms of Marketing and Promotion

\begin{tabular}{|c|c|c|c|c|c|c|}
\hline \multirow[b]{2}{*}{ The community... } & $\begin{array}{l}{[1]} \\
\text { VL }\end{array}$ & $\begin{array}{c}{[2} \\
] \\
\mathrm{L}\end{array}$ & $\begin{array}{l}{[3]} \\
\mathrm{M}\end{array}$ & $\begin{array}{l}{[4]} \\
\mathrm{H}\end{array}$ & $\begin{array}{l}{[5]} \\
\mathrm{VH}\end{array}$ & \multirow[t]{2}{*}{$\begin{array}{c}\mathrm{AW} \\
\mathrm{M}\end{array}$} \\
\hline & & & & & & \\
\hline $\begin{array}{l}\text { 1. promotes the } \\
\text { potential tourism } \\
\text { offerings of the } \\
\text { place through tour } \\
\text { guides, fliers, } \\
\text { broadcast and print }\end{array}$ & 1 & 7 & 64 & 153 & 175 & 4.24 \\
\hline
\end{tabular}

\begin{tabular}{|c|c|c|c|c|c|c|}
\hline media. & & & & & & \\
\hline $\begin{array}{l}\text { 2. helps in the } \\
\text { distribution of } \\
\text { fliers and } \\
\text { brochures about } \\
\text { the tourist } \\
\text { destinations in } \\
\text { their area. }\end{array}$ & 5 & 10 & 88 & 152 & 145 & 4.06 \\
\hline $\begin{array}{c}\text { 3. joins and } \\
\text { organizes festivals } \\
\text { and events that } \\
\text { further promote the } \\
\text { tourism } \\
\text { destinations in } \\
\text { their place. }\end{array}$ & 2 & 12 & 74 & 165 & 147 & 4.11 \\
\hline $\begin{array}{l}\text { 4. speaks highly of } \\
\text { their tourist } \\
\text { attractions to the } \\
\text { local and foreign } \\
\text { visitors and } \\
\text { becomes the most } \\
\text { effective medium } \\
\text { for the marketing } \\
\text { and promotion of } \\
\text { the tourist } \\
\text { destinations in } \\
\text { their place }\end{array}$ & 1 & 11 & 68 & 172 & 148 & 4.14 \\
\hline $\begin{array}{l}\text { 5. assists the local } \\
\text { government in the } \\
\text { protection and } \\
\text { sustainability of } \\
\text { tourist destinations } \\
\text { through the } \\
\text { enforcement of } \\
\text { local ordinances. }\end{array}$ & 4 & 8 & 67 & 175 & 146 & 4.13 \\
\hline Mean & & 4. & nigi & nvo & ent & \\
\hline
\end{tabular}

VL- very low involvement; $L$-low involvement, $M$ Moderate involvement, $\mathrm{H}$-High involvement, VH- Very high involvement

The table above illustrates the extent of the involvement of the community in the sun and beach tourism industry as to marketing and promotion. The following are the results of the survey: the community exhibited very high involvement in promoting the potential tourism offerings of the place to the local and foreign tourists through tour guides, fliers, broadcast and print media with one hundred seventy five (175) respondents, high involvement was also shown by means of the residents helping in the distribution of fliers and brochures about the tourist destinations in their area as answered by one hundred fifty two (152) respondents, the community also was highly involved in joining and 
organizing festivals and events that further promote the tourism destinations in their place, speaking highly of their tourist attractions to the local and foreign visitors and becomes the most effective medium for the marketing and promotion of the tourist destinations in their place by speaking only good things about these tourist attractions and in assisting the local government in the protection and sustainability of tourist destinations through the enforcement of local ordinances with frequencies of 165 , 172 and 175 respectively.

With a mean of 4.13 , the results only divulge that the community near and around the sun and beach tourist destinations are highly involved in marketing and promoting the sun and beach tourism industry in the Province of Batangas. This also shows the pride of the residents and community dwellers of the existence of sun and beach tourist destinations in the areas under focus.

\section{Environmental Protection}

Table 7 shows the extent of involvement of the community in the sun and beach tourism industry in Batangas in terms of environmental protection.

Table.7: Extent of Involvement of the Community in the Sun and Beach Tourism Industry in Batangas in Terms of Environmental Protection

\begin{tabular}{|c|c|c|c|c|c|c|}
\hline $\begin{array}{c}\text { Indicators } \\
\text { The community... }\end{array}$ & $\begin{array}{c}{[1} \\
] \\
\mathrm{V} \\
\mathrm{L}\end{array}$ & $\begin{array}{c}{[2} \\
] \\
\mathrm{L}\end{array}$ & $\begin{array}{c}{[3} \\
] \\
M\end{array}$ & $\begin{array}{l}{[4]} \\
\mathrm{H}\end{array}$ & $\begin{array}{l}{[5]} \\
\mathrm{V} \\
\mathrm{H}\end{array}$ & AWM \\
\hline $\begin{array}{l}\text { 1. helps in preserving } \\
\text { the environment } \\
\text { particularly the marine } \\
\text { life around the sun and } \\
\text { beach tourism }\end{array}$ & 1 & 12 & 66 & 169 & $\begin{array}{c}15 \\
2\end{array}$ & 4.15 \\
\hline $\begin{array}{l}\text { 2. helps in preserving } \\
\text { the natural "feel" and } \\
\text { "look" of the resorts } \\
\text { near their houses and } \\
\text { residences. }\end{array}$ & 1 & 11 & 56 & 169 & $\begin{array}{c}16 \\
3\end{array}$ & 4.21 \\
\hline $\begin{array}{l}\text { 3. helps in the } \\
\text { restoration and } \\
\text { preservation of the } \\
\text { natural setting of the } \\
\text { beach destinations in } \\
\text { their place. }\end{array}$ & 1 & 12 & 61 & 176 & $\begin{array}{c}15 \\
0\end{array}$ & 4.16 \\
\hline $\begin{array}{l}\text { 4. encourages tourists } \\
\text { to utilize environment- } \\
\text { friendly materials and } \\
\text { biodegradable utensils } \\
\text { during their picnics }\end{array}$ & 1 & 13 & 81 & 155 & $\begin{array}{c}15 \\
0\end{array}$ & 4.10 \\
\hline $\begin{array}{l}\text { 5. helps in keeping the } \\
\text { vicinity of the beach }\end{array}$ & 2 & 14 & 74 & 164 & $\begin{array}{c}14 \\
6\end{array}$ & 4.10 \\
\hline
\end{tabular}

\begin{tabular}{c|l|l|l|l|l|l}
$\begin{array}{c}\text { resorts clean and } \\
\text { hygienic. }\end{array}$ & & & & & & \\
\hline Mean & \multicolumn{5}{c}{$4.14($ High Invol ve ment) } \\
\hline
\end{tabular}

VL- very low involvement; $L$-low involvement, $M$ Moderate involvement, H -High involvement, VH- Very high involvement

The table above illustrates the extent of the involvement of the community in the sun and beach tourism industry as to environmental protection. The indicators used were able to reveal that in the environmental aspect, the community exhibited high involvement in preserving the environment particularly the marine life around the areas where the sun and beach tourism is active and functional with a frequency of 169 , preserving the natural "feel" and "look" of the resorts near their houses and residences by properly labeled trash cans and bins for tourists' wastes with a frequency of 169 , the restoration and preservation of the natural setting of the sun and beach destinations in their place with a frequency of 176, the utilization of environment-friendly materials and biodegradable utensils during their picnics and party time with a frequency of 155 and in keeping the vicinity of the beach resorts clean and hygienic by means of collecting improperly disposed trash from tourists and visitors with a frequency of 164 .

With a mean of 4.14 , the residents near and around the sun and beach tourist destinations in the Province of Batangas are highly involved in the environmental protection of its waters and marine life. This further shows that even if the residents and community dwellers are already open to the development and progress of their places, they still have a high regard to the protection and preservation of the environment which nurture the beauty and bounty of these sun and beach havens.

Having presented individually the extent of involvement of the community in the sun and beach tourism industry in the Province of Batangas, the table below shows the summary of the findings as to the residents' involvement in maintaining peace and security, marketing strategies and promotion of the said sun and beach tourist destinations and the involvement of the community in the environmental protection of the places with sun and beach tourism industry.

Table.8: Summary of the Extent of Involvement of the Community in the Sun and Beach Tourism Industry in Batangas

\begin{tabular}{c|c|c}
\hline Area of concern & Mean & $\begin{array}{c}\text { Extent of } \\
\text { involvement }\end{array}$ \\
\hline Peace and security & 4.23 & High \\
\hline $\begin{array}{c}\text { Marketing and } \\
\text { promotion }\end{array}$ & 4.13 & High \\
\hline
\end{tabular}




\begin{tabular}{c|c|c}
\hline $\begin{array}{c}\text { Environmental } \\
\text { protection }\end{array}$ & 4.14 & High \\
\hline $\begin{array}{c}\text { Average Weighted } \\
\text { Mean }\end{array}$ & $\mathbf{4 . 1 7}$ & High \\
\hline
\end{tabular}

With the presented tabulated summary, the residents of the province are highly involved in all areas of concern with means of 4.23 for peace and security, 4.13 for marketing and promotion and 4.14 for environmental protection. This may mean that the residents of Batangas give high regard to a quiet and peaceful community, are beaming with pride of the existence of the sun and beach tourist destinations in their respective localities and advocates the protection and preservation of the environment.

\section{FINDINGS}

The following are the finding revealed by the study.

\section{Years of Existence}

In terms of years of existence, San Juan is the oldest of the four municipalities under scrutiny as it has existed for one hundred sixty nine (169) years, followed by Nasugbu which has existed for one hundred sixty five (165), third is Lian at one hundred two years (102) and the Municipality of Mabini which age as a town is ninety nine years (99).

Class

As to class, all three (3) municipalities in focus namely Mabini, Nasugbu and San Juan are first class municipalities while Lian is third class in classification.

Population

As far as population is concerned, the Municipality of Nasugbu is the most populous in the NSO Census of 2010, NSO Census of 2015 and in the projected population NSO Census of 2016.It also has the highest projected growth rate of $2.21 \%$. The Municipality of San Juan followed next. The least populous municipality appears to be Mabini with a projected growth rate of $1.38 \%$ per year as compared with the second least populous Lian with a projected growth rate of $1.97 \%$ per year.

\section{Geographical Dispersion}

When it comes to geographical dispersion, all the municipalities under focus can be reached conveniently by sun and beaches fanatics because of their acces sibility to the public.

\section{Sources of Livelihood}

The residents of the municipalities under focus are engaged into formal employment, agriculture related and fishing related sources of livelihood. There are commonalities as to the sources of living as discussed which feature the native products being produced by each town and the services and expertise which may be provide to the visitors of the sun and beach tourist destinations in their respective areas.

EXTENT OF INVOLVEMENT OF THE COMMUNITY

\section{IN THE SUN AND BEACH TOURISM INDUSTRY} IN BATANGAS

Peace and Security

In the extent of involvement of the community in terms of peace and security, it was found out that the residents of the province are highly involved in the said area of concern with a mean of 4.23 .

Marketing and Promotion

In the extent of involvement of the community in terms of marketing and promotion, it was found out that the residents of the province are highly involved in the said area of concern with a mean of 4.13 .

\section{Environmental Protection}

In the extent of involvement of the community in terms of environmental protection, it was found out that the residents of the province are highly involved in the said area of concern with a mean of 4.14.

\section{CONCLUSIONS}

With all the presentations above as to the status of the sun and beach tourism industry in the Province of Batangas, the following conclusions were reached by the researcher:

1. The beach tourism industry in the province is already thriving and progressive.

2. The accessibility of the province via its diversion roads, road widening projects and construction of alternate routes for visitors to easily reach the place is advantageous to the province's sun and beach tourist destinations.

3. The residents of the province fully understand their opportunities to a number of sources of livelihood which the sun and beach tourist destinations in their respective localities had offered them.

4. The sun and beach tourism industry in the province can give the residents better job opportunities even without going out of their localities for work.

\section{RECOMMENDATIONS}

1. Tie-up among the concerned local government units and other related agencies must be strengthened in order to foster the progress and development of the sun and beach tourism industry in the province.

2. The community must be kept involved with the concerns of the said industry in order for the resort owners and managers to be able to work 
hand in hand with them for the benefit of both parties involved.

3. The municipal officers must be in constant communication and coordination with the Provincial Tourism Office in terms of the promotional strategies and marketing of the sun and beach tourism industry.

4. The community must be made aware of their important responsibilities as keepers of peace and security, protector of their environment and the most effective marketing and promotion icon of their locality.

\section{REFERENCES}

[1] Lekner, A. and Bosker D., 1999, "Tourism and Hospitality Management".

[2] Corina B. Mejia et.al. (2013), "Involvement of the Community in Promoting Marine Biodiversity as Tourist Attraction". Journal of International Academic Research for Multidisciplinary, 1(7), 151158.

[3] Leslie Allaine E. Aguda et.al. (2013), "Effects of Heritage Tourism to the Municipality of Taa, Batangas, Philippines". Educational Research International, 2(1), 91-95.

[4] Lancion C.(1999) Fast Facts About Philippine Province, Tahanan Pacific Inc.

[5] Local Government Units Annual Accomplishment Reports of the Municipality of Mabini.

[6] Local Government Units Annual Accomplishment Reports of the Municipality of Lian.

[7] Local Government Units Annual Accomplishment Reports of the Municipality of Nasugbu

[8] Local Government Units Annual Accomplishment Reports of the Municipality of San Juan.

[9] MPDC Reports, Municipality of Mabini

[10] MPDC Reports, Municipality of Lian

[11] MPDC Reports, Municipality of Nasugbu

[12] MPDC Reports, Municipality of San Juan

[13] Philippine Statistics Authority (PSA)

[14] Provincial Government Units of the Province of Batangas.

[15] World Tourism Organization (WTO) (2005). Yearbook of Tourism Statistics. Madrid 